EUTOMIA

Marcia Cavendish Wanderley ${ }^{i}$

\title{
O AMOR
}

Um poema não se faz assim, de encomenda,

mas é bom que pressione

porque às vezes outras leituras nos assomam,

e levam com elas poemas para o fundo

desse golfo dourado que são as ideias.

Não me queixo porque sei que voltarei renovada.

Outros versos farei de coisas práticas

falando do ser ou do sentido da história,

das escolas do pensamento metafísico

ou heideggeriano,

para ocultar o desejo que pulsa nas artérias

de viver mais um pouco aquele verão louco

neste inverno que, sem ser chamado,

beija meus cabelos.

\section{ENQUANTO ANDAMOS}

Onde está o amor? Não sei, suspeito.

Atrás das montanhas do prédio.

Não está na cama,

nos fumos vagos de uma

Habana libre; 
em Nova York

onde pensei: felicidade existe.

E certamente não está em São Paulo

lugar talhado para androides

pessoas que não vivem mas consomem

o que o monstro come e lhes devolve.

Tudo é cinzento na vida quando

cor não tiramos da poeira do sapato,

enquanto andamos.

O amor não está atrás do peito,

está embaixo do meu pé direito... esmagado.

\section{TODOS DIZEM I LOVE YOU}

Há algo que impede o recifense de dizer

-eu te amo,

como abertamente fazem

os artistas do cinema americano.

Não que o amor seja menor, ou menos denso

em coração nordestino cravado por sentimentos

doces como o mel de engenho em seu pretume,

de travo amargo de espiga, quando a corta

a aguda faca do ciúme.

É uma espécie de vergonha que deixa a palavra muda

e até baixa a estatura, daquele que só com os olhos

consegue passar, mareiro, o embaraço

de alguém que só sabe amar em jorro alto

cobrindo todos os poros e buracos,

e não tem dique que pare tanta água

que salobra brota em partes muito quietas do seu corpo

e impedem que este cristão diga como o americano:

Eutomia, Recife, 26(1): 302- 305, Dez. 2020 
eu te amo.

\section{PREDOMÍNIO DO NEGRO}

No reino dos cajus fui princesa desatenta

sem notar que eram bichadas as frutas suculentas

somente a dor me despertou

do verde sonho adolescente

e instaurou a mudança no tempo do mundo.

Habitei duas cidades e a nenhuma pertenci

de ambas sinto saudade

Delas guardo cheiros ácidos: fruta, peixe, mar

da juventude a louca tempestade.

No Arpoador naufraguei e retornei inteira.

Mas tive que nadar para aprender

o árduo ofício de viver em terra estranha

mesmo que brasileira.

Vivi momentos mágicos dormindo

a realidade era a parede acesa

refletindo pedra, cal e a desolada certeza

do tempo que percorre nossa pele e ossos

Em direção ao negro predomínio da morte.

\section{BÉRGSON EM PERNAMBUCO}

Nossa visão do tempo é totalmente falsa, disse-me Bérgson numa noite de orgia.

O espaço se intromete sem ter sido chamado, e busca assassinar a rosa da alegria. 
Só o tempo do amor é verdadeiro.

Dura para sempre ou se apaga num átimo

É tempo raro, trêfego, medido pelo vento, penetra nas folhas e esparge seu perfume.

Ao senti-lo sabemos a que horas estamos, em qual península, em qual país estranho.

Quero eu em teus braços comandar o tempo, domar seus elementos, seus espaços neutros, deixar que ele se estenda, extinga ou desanime de passar ou ficar, porém se torne infindo

\section{A IDADE DO ENTENDIMENTO}

A que vem a vida?

Somos fisgados, logo de chofre

com velhas iscas ardidas e salgadas

que nos parecem suaves e doces.

Sofremos presos

para sofrer mais ainda se escapamos.

Quanto mais presos pelas guelras

mais gozamos

neste banquete exaurido

sempre novo.

A cada recém-chegado.

\footnotetext{
' Marcia Cavendish Wanderley, professora de Sociologia da Literatura (aposentada) da Universidade Federal Fluminense (UFF), Doutora em Sociologia pela PUC-RJ, com quatro livros de poesia publicados, entre os quais "O Terceiro Jardim" e "A Idade do Entendimento".
} 